\title{
Who's Getting Cited: Representation of Women and Non-White Scholars in Major American Criminology and Criminal Justice Journals Between 1986-2005
}

\author{
Bitna Kimª and Paul M. Hawkins
}

Indiana University of Pennsylvania, Department of Criminology, Indiana, Pennsylvania 15705, USA

\begin{abstract}
This article presents findings from an ongoing study of the integration of women and non-white scholarship into the discipline of criminology and criminal justice. The most-cited women and non-white scholars in six major American journals were determined for 1986-2005 to investigate (1) if the dissemination of published research findings in criminology and criminal justice (CCJ) is affected by gender and race/ethnicity and (2) if changes in scholarly influence of women and non-white scholars in CCJ over 20 years exists. A number of explanations are suggested to account for gender and racial differentials in citation rates.
\end{abstract}

Keywords: Journal publication, gender, ethnicity, citations.

\section{INTRODUCTION}

Academe has traditionally been a white maledominated profession, even though this varies considerably by discipline (Rice, Terry, Miller, and Ackerman 2007). The discipline of criminology and criminal justice is not an exception. Feminist scholars often criticize criminology as a "discipline dominated by men" and "mainly about academic men studying criminal men" (Chesney-Lind 1989; Daly and ChesneyLind 1988; Heidensohn 1987; Hughes 2005; Miller, Wright, and Smith 2000; Morris and Gelsthorpe 1991; Renzetti 1993; Naffin 1996; Smart, 1976).

Previous rich studies confirm that mainstream criminology journals remain androcentric, publishing males' work focusing more on men than on women (Hannon and Dufour 1998), whereas women remain underrepresented as the authors of articles in leading criminology journals and on editorial boards of these journals (Eigenberg and Baro 1992; Miller, Wright, and Smith 2000). Textbooks in criminology and criminal justice remain androcentric as well. Miller, Wright, and Smith (2000) examine this issue through an analysis of citation patterns in twenty-five introductory criminology textbooks published from 1992 to 1996. Their study found that criminology textbooks were more likely to cite males than females who conduct women and crime research.

While the number of articles published by racial non-whites in mainstream criminology and criminal justice journals increased, recent research shows they

*Address correspondence to this author at the Indiana University of Pennsylvania, Department of Criminology, Indiana, Pennsylvania 15705, USA; Tel: 724-357-5931; Fax: 724-357-4018; E-mail: bitna.kim@iup.edu remain limited (Gabbidon et al. 2004; Del Carmen and Bing 2000; Ross and Edwards 1998; Tatum 2002; Young and Sulton 1996). Specifically, several studies of African American contributions in leading journals and textbooks exist (Free 1999; Gabbidon and Taylor Greene 2001; Taylor Greene, Gabbidon, and Ebersole 2001; Taylor Greene and Gabbidon 2003). While during the 1980s a number of African American scholars gained increased attention, including Lee $P$. Brown, Julius Debro, Daniel Georges-Abeyie, Coramae Mann, Darnell Hawkins, and Vernetta Young (Gabbidon and Tylor Greene 2001), several overviews of African American scholars' contributions suggest that most other African American criminologists and their contributions remain on the periphery of the discipline (Taylor Greene and Gabbidon 2003). Young and Sulton (1991), Young and Taylor Greene (1995), and Gabbidon et al. (2004) also recognized the problem of exclusion of works by African American scholars and their contributions from the discipline of criminology (Taylor Greene and Gabbidon 2003). Furthermore, findings from a content analysis of African American presence in textbooks (Gabbidon and Taylor Greene 2001) and the examination of their contributions in theoretical research appearing in criminology and criminal justice journal articles published during the 1990s (Taylor Greene and Gabbidon 2003) support previous research reporting that scholarship of African Americans is underrepresented (del Carmen and Bing 2000) and generally excluded (Free 1999; Taylor Greene and Gabbidon 2003).

It should be noted that recent research (Gabbidon et al. 2004) suggests African Americans made moderate progress during the ensuing decade since 
Young and Sulton's (1991) report. Focusing on African American faculty and graduate students, Gabbidon et al. (2004) found this moderate progress through leadership positions held in criminology and criminal justice programs, contributions to journals and other scholarly outlets, membership/involvement in criminal justice professional associations, recognition of achievements, roles in policymaking, acquisition of funding sources, press acknowledgment, and enrollment at historically black colleges and universities. Gabbidon et al. (2004) conclude similarly to Young and Sulton (1991) in that "African American scholars have made and continue to make valuable contributions to the field of criminology [and criminal justice]" (Young and Sulton, 1991:115) yet, they "hope that 10 years from now, we can write a different closing summation" (Gabbidon et al. 2004:404) suggesting the importance of African American progress and contribution in order to achieve enriched representation within the disciplines of criminology and criminal justice.

\section{THE PRESENT RESEARCH}

In order to investigate the influence of women and non-whites in the discipline of criminology and criminal justice, it is important to understand that most previous studies examined works of women or African American scholars published in textbooks (Gabbidon and Taylor Greene 2001; Miller et al. 2000). According to recent studies on the contributions of non-whites and women in relation to criminology and criminal justice book publishing (Gabbidon and Collins 2012; Gabbidon and Martin 2010), the work of African American sociologist W.E.B. Dubois titled, The Philadelphia Negro (1899) was considered by other criminology and criminal justice scholars to be one of the top 14 most significant book publications prior to 1900 (Gabbidon and Martin 2010). Additionally, Gabbidon and Collins (2012) used Google Scholar to find that the most cited book $(5,695)$ authored by a woman was Judith Herman's Trauma and Recovery (1992) and the most cited book $(9,177)$ authored by an African American was Julius Wilson's The Truly Disadvantaged (1987).

Although few studies focusing on the presence of women and non-whites in leading journals subsist, those studies analyzed articles published before 2000 (Eigenberg and Baro 1992; Miller et al. 2000; Taylor Greene and Gabbidon 2003), Additionally, prior studies remain limited by focusing only on theoretical research appearing in criminology and criminal justice journal articles and the contribution of African American scholars rather than additional non-white scholars (Free 1999; Gabbidon and Taylor Greene 2001; Taylor Greene and Gabbidon 2003; Taylor Greene, Gabbidon, and Ebersole 2001; Young and Taylor Greene 1995; Young and Sulton 1991). Moreover, there has been no direct comparison between women and men or between white and non-whites in terms of their presence in the leading criminology and criminal justice journals. Rather, previous studies focused on either only women scholars or only African American scholars. For example, Rice, Terry, Miller and Ackerman (2007) studied the publication trajectories of 88 female scholars who graduated between 1996-2006 in Criminology and Criminal Justice while Taylor Greene and Gabbidon (2003) investigated the presence of African American contributions in theoretical research appearing in criminology and criminal justice journal articles published during the 1990s.

This article extends previous research on the influence of women and non-whites in the discipline of criminology and criminal justice by examining the sex and race of the most-cited scholars in major American criminology and criminal justice journals during the 1986-2005 time period. Identifying the most-cited women and non-white authors helps to discover changes in the scholarly influence of women and nonwhites in criminology and criminal justice throughout a particular time period and, hence, helps to document women and non-white presence in major CCJ journals.

Given the lists of the most-cited scholars in six major American CCJ journals from the previous research (Cohn and Farrington 1994, 1998a, 2007a; Cohn 2011), this article replicates the citation analysis to assess the most-cited women and non-white scholars in three major American criminology journals (Criminology - CRIM, Journal of Quantitative Criminology - JQC, Journal of Research in Crime and Delinquency - JRCD) and three major American criminal justice journals (Justice Quarterly - JQ, Journal of Criminal Justice - JCJ, Criminal Justice and Behavior - CJB) from 1986-2005. One major benefits of citation analysis is that raw data are readily accessible to anyone who wishes to attempt to repeat the previous analyses (Cohn and Farrington 1994, 1998a, 2007a; Cohn 2011).

\section{Counting Citations}

The most-cited scholars remain one method for measuring influence in criminology and criminal justice 
(Cohn and Farrington 1998a). In the past 30 years, citation analysis has become broadly used in CCJ as a way of measuring influence and prestige (Cohn 2011; Cohn and Farrington 1994, 1998a, 2007; Wright, Bryant, and Miller 2001; Wright and Friedrichs 1998; Wright and Miller 1998, 1999; Wright and Sheridan 1997).

The use of citation analysis provides us with a quantitative method for determining scholarly influence in CCJ. The rationale for using citation analysis is that a good work is a work that other scholars find useful and consequently cite in their own works (Christenson and Sigelman 1985; Cohn, 2011). As a consequence, if a scholarly work is highly cited, it implies that the scholar's colleagues find the work significant and valuable. Research shows that citation counts are highly correlated with other measures of scholarly influence, including ratings by colleagues (Cohn 2011; Myers 1970), the receipt of scholarly awards and prizes (Cole and Cole 1971), election to major offices in professional associations (Rushton and Endler 1979), and the publication rates of scholars (Cohn 2011; Cohn and Farrington 2007a; Gordon and Vicari 1992; Miller et al. 2000). However, unlike most of the measures of scholarly influence, citation analysis affords an objective, quantitative index, which is much less influenced by personal bias or special interest (Cohn 2011; Cohn and Farrington 2007). In general, it was concluded that large numbers of citations provided an imperfect but, nonetheless, reasonably valid measure of scholarly influence (Cohn and Farrington 1998a).

Cohn and Farrington (1994, 1998a, 2007a) and Cohn's (2011) research focusing highly on citations in six major American CCJ journals permit a unique analysis of citation trends over 20 years. In order to examine scholarly influence in criminology and criminal justice, Cohn and Farrington (1994) investigated the most-cited scholars in six major American journals in criminology and criminal justice from 1986-1990. The same methods were exactly repeated to assess the most-cited scholars in these journals during the period 1991-1995 (Cohn and Farrington 1998a), 1996-2000 (Cohn and Farrington 2007a), and 2001-2005 (Cohn 2011).

Cohn and Farrington (1994, 1998a, 2007a) and Cohn (2011) selected six major American journals: three major American criminology journals (Criminology - CRIM, Journal of Quantitative Criminology - JQC, Journal of Research in Crime and Delinquency - JRCD) and three major American criminal justice journals
(Justice Quarterly - JQ, Journal of Criminal Justice JCJ, Criminal Justice and Behavior - CJB). "Articles" included research notes, comments, and rejoinders, but excluded book reviews, editorials, letters, and obituaries. Every cited author was counted (not just first authors), except institutional authors (e.g. National Institute of Justice) whom were excluded. Unpublished reports and conference papers were included if they were cited. All self-citations were excluded. Co-author citations were noted but not excluded from the analyses (Cohn 2011). From the analysis of 90,021 cited authors in six journals in 2001-2005, Cohn and Farrington (2007a) identified 67,267 cited authors in 1996-2000, Cohn and Farrington (1998a) 49,845 cited authors in 1991-95, Cohn and Farrington (1994) analyzed 44,429 cited authors in 1986-90, and Cohn and Farrington (1994, 1998a, 2007a) and Cohn (2011) concluded the lists of the 50 most-cited scholars in six journals during a specified time period.

The current study first required making a combined list of all scholars ranked at least once on the lists of 50 most-cited scholars in any of six journals in 1986-1990 (Cohn and Farrington 1994), in 1991-1995 (Cohn and Farrington 1998a), in 1996-2000 (Cohn and Farrington 2007a), and in 2001-2005 (Cohn 2011). This study found 350 scholars named at least once on the lists of 50 most-cited scholars in any of six journals over a 20 year time period. For these 350 scholars, their sex (male vs. female) and race (white vs. non-white) were examined. Women and non-white scholars were identified in two ways. First, based on several years of research, the authors have personal knowledge of these individuals based upon experience within the discipline. To maximize the accuracy of the data, the authors also consulted with several senior scholars in the discipline of criminology and criminal justice and thoroughly conducted Internet searches (Taylor Greene and Gabbidon 2003). Using these methods, the sex of $98.9 \%(n=346)$ of these scholars was identified, while the race (white vs. non-white) of $91.7 \%(n=318)$ was identified.

Table 1 shows the sex and race of the 350 most cited scholars in any of the six journals in 1986-2005. As shown in Table $1,88.9 \%$ is white $(\mathrm{N}=311)$, while only $2.0 \%(\mathrm{~N}=7)$ are non-white. In terms of the sex, $84.9 \%(\mathrm{~N}=297)$ are male scholars, whereas $14.0 \%(\mathrm{~N}$ = 49) are female scholars. Table 1 shows white males $(77.1 \%, N=270)$ as the dominant category of mostcited scholars to appear in the top 50 at least once in any of the six journals in 1986-2005, while whitefemales $(12.6 \%, N=44)$ are second. White males $(N=$ 
Table 1: Sex and Race (White vs. Non-White) of the 350 Most Cited Scholars in Any of the Six Journals in 1986-2005

\begin{tabular}{|c|c|c|c|c|c|c|}
\hline & & & \multicolumn{4}{|c|}{ Sex } \\
\hline & & & Male & Female & Unidentified & Total \\
\hline \multirow{8}{*}{ Race } & \multirow{2}{*}{ White } & Count & 270 & 44 & 0 & 311 \\
\hline & & $\%$ of Total & $77.1 \%$ & $12.6 \%$ & $.0 \%$ & $88.9 \%$ \\
\hline & \multirow{2}{*}{ Non-White } & Count & 6 & 1 & 0 & 7 \\
\hline & & $\%$ of Total & $1.7 \%$ & $.3 \%$ & $.0 \%$ & $2.0 \%$ \\
\hline & \multirow{2}{*}{ Unidentified } & Count & 21 & 4 & 4 & 29 \\
\hline & & $\%$ of Total & $6.0 \%$ & $1.1 \%$ & $1.1 \%$ & $8.3 \%$ \\
\hline & \multirow{2}{*}{ Total } & Count & 297 & 49 & 4 & 350 \\
\hline & & $\%$ of Total & $84.9 \%$ & $14.0 \%$ & $1.1 \%$ & $100.0 \%$ \\
\hline
\end{tabular}

$270)$ and white females $(\mathrm{N}=44)$ combined for $88.9 \%$ of the total representation $(\mathrm{N}=311)$ of the most-cited scholars to appear at least once in the top 50 in any of the six journals in 1986-2005. Comparatively, there are six non-white males (1.7\%) and only one non-white female $(.3 \%)$, which accounted for $2.0 \%$ of the total representation of most-cited scholars to appear at least once in the top 50 in any of the six journals in 19862005. Furthermore, noticeable differences in representation between white males $(77.1 \%)$ and nonwhite males $(1.7 \%)$ as well as between white females $(12.6 \%)$ and non-white females $(.3 \%)$ exist. It is important to note that among the 350 most-cited scholars in table 1 , a total of $29(8.3 \%)$ are unidentified for this study. There are 21 males $(6.0 \%)$ and four females $(1.1 \%)$ whose race was unidentified, and four $(1.1 \%)$ additional individuals with an unidentified sex. In addition, there are four scholars (1.1\%) with unidentified race and sex.

\section{FINDINGS}

\section{American Criminology Journals}

From the lists of the 50 most-cited scholars in Criminology (CRIM) in 2001-2005 (Cohn 2011), 19962000 (Cohn and Farrington 2007a), 1991-1995 (Cohn and Farrington 1998a), and 1986-1990 (Cohn and Farrington 1994), women and non-white scholars are identified for the current study. Table 2 shows the most-cited women and non-white scholars in CRIM in 2001-05. Among 50 most-cited scholars in CRIM in 2001-2005 (Cohn 2011), twelve (24.0\%) are women and non-whites. As shown in Table 2, the highest rank among women and non-white scholars in the top 50 in 2001-05 was Terrie E. Moffitt (white female), who was ranked 2nd. Ruth D. Peterson (46) was the only non- white female scholar who was ranked in the top 50 . The most-cited non-white male scholar was Alex R. Piquero, who was ranked 7 th.

Table 2 also shows the comparable rankings of these women and non-white scholars in CRIM from the three previous time periods: 1996-2000, 1991-95, and 1985-90. From the lists of the 50 most-cited scholars in CRIM, 6 scholars (12\%) in 1996-2000, 7 scholars (14\%) in 1991-95, and 6 scholars (12\%) in 1986-90 were women and non-white. Moffitt (white female, rank 20th) was again the highest ranked woman and nonwhite scholar in CRIM from 1996-2000. A non-white female scholar ranked in the top 50 in CRIM in 19962000, 1991-95, or 1986-90 appeared absent from the list. The most-cited non-white male scholar in CRIM from 1996-2000 (24.5) and 1991-95 (45) was William J. Wilson. There was not a non-white male scholar ranked in the top 50 in CRIM in 1986-90. Jacqueline Cohen, a white female, was the highest ranked scholar among women and non-whites ranked on the list of the most-cited scholars in CRIM in 1991-95 (6th) and $1986-90$ (8th). Cohen was again ranked in the top 50 in CRIM from 2001-05 (41st) and 1996-2000 (32nd).

Twelve $(60 \%)$ of these 20 women and non-white scholars in Table 2 had been ranked in the top 50 in 2001-2005, 6 (30\%) were in the top 50 in 1996-2000, 7 $(35 \%)$ were in the top 50 in $1991-95$, and $6(30 \%)$ were in the top 50 in 1986-90. Four of the most-cited women and non-white scholars in 2001-05 were also ranked in the top 50 in 1996-2000, while three were in the top 50 in 1991-95, and one was in the top 50 in 1986-90. Of the six most-cited women and non-whites in 19962000 , four were ranked in the top 50 in 1991-95, and two were ranked in the top 50 in 1986-90. Of the seven most-cited women and non-white scholars in 1991-95, three were ranked in the top 50 in 1986-90. 
Table 2: Most-Cited Women and Non-White Scholars in Criminology

\begin{tabular}{|c|c|c|c|c|c|c|}
\hline Name & Sex & Race & $\begin{array}{c}\text { Rank in } \\
2001-2005\end{array}$ & $\begin{array}{c}\text { Rank in } \\
1996-2000\end{array}$ & $\begin{array}{c}\text { Rank in } \\
1991-1995\end{array}$ & $\begin{array}{c}\text { Rank in } \\
1986-1990\end{array}$ \\
\hline Terrie E. Moffitt & Female & White & 2.0 & 20.0 & & \\
\hline Alex R. Piquero & Male & Non-White & 7.0 & & & \\
\hline William J. Wilson & Male & Non-White & 17.0 & 24.5 & 45.0 & \\
\hline Adele E. Forth & Female & White & 17.0 & 24.5 & 45.0 & \\
\hline Janet L. Lauritsen & Female & White & 30.0 & & & \\
\hline Patricia L. McCall & Female & White & 36.5 & & & \\
\hline Megda Stoughamer-Loeber & Female & White & 41.0 & & & \\
\hline Jacqueline Cohen & Female & White & 41.0 & 32.0 & 6.0 & 8.0 \\
\hline Elijah Anderson & Male & Non-White & 46.0 & & & \\
\hline Ruth D. Peterson & Female & Non-White & 46.0 & & & \\
\hline Cassia Spohn & Female & White & 46.0 & & & \\
\hline Felton Earls & Male & Non-White & 48.0 & & & \\
\hline Suzanne S. Ageton & Female & White & & 50.0 & 16.5 & 15.5 \\
\hline Christy A. Visher & Female & White & & & 25.5 & 29.0 \\
\hline Lee N. Robins & Female & White & & & 39.0 & \\
\hline Cathy S. Widom & Female & White & & & 45.0 & \\
\hline Eleanor T. Glueck & Female & White & & & & 13.0 \\
\hline llene H. Nagel/Bernstein & Female & White & & & & 45.5 \\
\hline Joan McCord & Female & White & & & & 45.5 \\
\hline
\end{tabular}

The highest new entrant among women and nonwhites into the top most-cited scholars in CRIM in 2001-05 was Alex R. Piquero (rank 7). Other notable entrants into the top 50 in 2001-05 were Janet L. Lauritsen, Patricia L. McCall, Megda SoughamerLoeber, Elijah Anderson, Ruth D. Peterson, Cassia Spohn, and Felton Earls. The most notable advancement in rank from 1996-2000 to 2001-05 was Terrie E. Moffitt (from 20 to 2). William J. Wilson and Adelle E. Forth also advanced their rankings from 1991-95 to 1996-2000 to 2001-05 (both from 45 to 24.5 to 17). From 1986-90 to 1991-95, Christy A Visher improved her ranking (from 29 to 25.5). Moving in the other direction was Jaqueline Cohen (initial improvement of 8 from 1986-90 to 6 in 1991-95; to 32 in 1996-2000 to 41 in 2001-2005). Suzanne S. Ageton also moved in the other direction (from 15.5 in 1986-90 to 16.5 in $1991-95$ to 50 in 1996-2000).

From the lists of the 50 most-cited scholars in the Journal of Quantitative Criminology (JQC) from 20012005 (Cohn 2011), 1996-2000 (Cohn and Farrington 2007a), 1991-1995 (Cohn and Farrington 1998a), and 1986-1990 (Cohn and Farrington 1994), women and non-white scholars are identified for the current study. Table 3 shows the most-cited women and non-whites in JQC in 2001-05. Among 50 most-cited scholars in JQC in 2001-2005 (Cohn 2011), six (12\%) were women and non-whites. As shown in Table 3, the highest rank among women and non-whites in 2001-05 was Terrie E. Moffitt (white female), who was ranked 9. Alex R. Piquero (rank 13) was the top ranked non-white male most-cited scholar in JQC in 2001-05. There was not a single non-white female scholar ranked in the top 50 in JQC in 2001-05.

Table 3 also shows the comparable rankings of these women and non-white scholars in JQC in the three previous time periods: 1996-2000, 1991-95, and 1985-90. From the lists of the 50 most-cited scholars in the JQC, 6 scholars (12\%) in 1996-2000, 6 scholars $(12 \%)$ in 1991-95, and 8 scholars (12\%) in 1986-90 were women and non-white. Jacqueline Cohen (6 in 1996-2000, 4 in 1991-1995, and 5 in 1986-90.5) was the highest ranked scholar among women and nonwhite scholars who were listed in the most cited scholar in JQC in 1996-2000, 1991-95, and 1986-90. There was not a non-white male scholar ranked in the top 50 in JQC in 1996-2000 and 1991-95, while Soumyo D. Moitra (non-white male) was ranked 49 in the top 50 in JQC in 1986-1990. There was not a non-white female scholar ranked in the top 50 in JQC in 1996-2000, 1991-95, or 1986-90.

Six $(35.3 \%)$ of these 17 women and non-whites in Table 3 had been ranked in the top 50 in 2001-05, six (35.3\%) had been ranked in the top 50 in 1996-2000, six (35.3\%) had been ranked in the top 50 in 1991-95, and eight (47\%) had been ranked in the top 50 in 198690. Only one of the most-cited women and non-white 
scholars in JQC in 2001-05 was ranked in the top 50 in 1996-2000. Two most-cited women and non-white scholars in 1996-2000 were ranked in the top 50 in 1991-95, while five in 1991-95 were also ranked in the top 50 in 1986-1990.

Jacqueline Cohen (white female) was the only one ranked in the top 50 in all four of the time periods (33.5 in 2001-05, 6 in 1996-2000, 4 in 1991-95, and 5.5 in 1986-90). Joan Petersilia (white female) was ranked in the top 50 in three of the time periods (36.5 in 1986-90 to 25.5 in $1991-95$ to 50.5 in 1996 to 2000 ). Adelle E. Forth was ranked in the top 50 in two non-consecutive time periods (from 43 in 1986-90 to 50 in 2001-05). Four (Terrie E. Moffitt, Alex R. Piquero, Patricia L. McCall, and Cassia Spohn) among the most-cited women and non-whites in JQC were able to obtain a ranking within the top 50 of the most-cited scholars in JQC in 2001-2005 while having not been ranked in the top 50 in JQC in the previous time periods.

From the lists of the 50 most-cited scholars in JRCD from 2001-2005 (Cohn 2011), 1996-2000 (Cohn and Farrington 2007a), 1991-1995 (Cohn and Farrington 1998a), and 1986-1990 (Cohn and Farrington 1994), women and non-whites are identified for the current study. Table 4 shows the most-cited women and nonwhite scholars in JRCD in 2001-05. Among 50 mostcited scholars in JRCD in 2001-2005 (Cohn 2011), seven (14\%) were women and non-whites. As shown in Table 4, the highest rank among women and non- whites in the top 50 in 2001-05 was Terrie E. Moffitt (white female), who was ranked 5. There was not a single non-white female scholar ranked in the top 50 in 2001-05, 1996-2000, 1991-95, or 1986-90. Christy A. Visher (rank 21.5; white female) was the highest ranked scholar among the most-cited women and nonwhites in JRCD in 1996-2000. There was not a single non-white male scholar ranked in the top 50 in JRCD in 1996-2000, 1991-95, or 1986-90. Suzanne S. Ageton (white female; rank 11 in 1991-95 and 25 in 1986-90) was the highest ranked scholar among the most-cited women and non-white scholars in JRCD in 1991-95 and 1986-90, while her ranking decreased in 19962000 to 43.

Eight $(57 \%)$ of these 14 women and non-white scholars in JRCD had been ranked in the top 50 in 2001-05, $6(43 \%)$ had been ranked in the top 50 in $1996-2000,4(29 \%)$ had been ranked in the top 50 in $1991-95$, and $4(29 \%)$ had been ranked in the top 50 in 1986-90. Two of the most-cited women and non-whites in JRCD in 2001-05 were ranked in the top 50 in 19962000, while one was ranked in the top 50 in 1991-95 and 1986-1990. Three of the most-cited women and non-white scholars in 1996-2000 were ranked in the top 50 in 1991-95, while two of these three were also ranked in 1986-90.

Jacqueline Cohen was ranked in the top 50 in JRCD in all four of the time periods (48.5 in 2001-05, 40 in 1996-2000, 27 in 1991-95, and 29.5 in 1986-90).

Table 3: Most-Cited Women and Non-White Scholars in Journal of Quantitative Criminology

\begin{tabular}{|c|c|c|c|c|c|c|}
\hline Name & Sex & Race & $\begin{array}{c}\text { Rank in } \\
2001-2005\end{array}$ & $\begin{array}{c}\text { Rank in } \\
1996-2000\end{array}$ & $\begin{array}{c}\text { Rank in } \\
1991-1995\end{array}$ & $\begin{array}{c}\text { Rank in } \\
1986-1990\end{array}$ \\
\hline $\begin{array}{c}\text { Terrie E. Moffitt } \\
\text { Alex R. Piquero } \\
\text { Jacqueline Cohen } \\
\text { Patricia L. McCall } \\
\text { Adelle E. Forth } \\
\text { Cassia Spohn } \\
\text { Joan McCord } \\
\text { Magda Stoughamer-Loeber } \\
\text { Carolyn R. Block } \\
\text { Peggy C. Giordano } \\
\text { Joan Petersilia } \\
\text { Christy A. Visher } \\
\text { Ann D. Witte } \\
\text { Suzanne S. Ageton } \\
\text { Cathy Streifel } \\
\text { Patricia Mayhew } \\
\text { Soumyo D. Moitra }\end{array}$ & $\begin{array}{l}\text { Female } \\
\text { Male } \\
\text { Female } \\
\text { Female } \\
\text { Female } \\
\text { Female } \\
\text { Female } \\
\text { Female } \\
\text { Female } \\
\text { Female } \\
\text { Female } \\
\text { Female } \\
\text { Female } \\
\text { Female } \\
\text { Female } \\
\text { Female } \\
\text { Male }\end{array}$ & $\begin{array}{l}\text { White } \\
\text { Non-White } \\
\text { White } \\
\text { White } \\
\text { White } \\
\text { White } \\
\text { White } \\
\text { White } \\
\text { White } \\
\text { White } \\
\text { White } \\
\text { White } \\
\text { White } \\
\text { White } \\
\text { Unidentified } \\
\text { Unidentified } \\
\text { Non-White }\end{array}$ & $\begin{array}{c}9.0 \\
13.0 \\
33.5 \\
41.5 \\
50.0 \\
50.0\end{array}$ & $\begin{array}{l}24.5 \\
31.5 \\
43.0 \\
46.5 \\
50.5\end{array}$ & $\begin{array}{c}25.5 \\
8.0 \\
14.0 \\
21.0 \\
32.0\end{array}$ & $\begin{array}{l}36.5 \\
22.5 \\
13.5 \\
31.5 \\
\\
22.5 \\
49.0\end{array}$ \\
\hline
\end{tabular}


Table 4: Most-Cited Women and Non-White Scholars in Journal of Research in Crime and Delinquency

\begin{tabular}{|c|c|c|c|c|c|c|}
\hline Name & Sex & Race & $\begin{array}{c}\text { Rank in } \\
2001-2005\end{array}$ & $\begin{array}{c}\text { Rank in } \\
1996-2000\end{array}$ & $\begin{array}{c}\text { Rank in } \\
1991-1995\end{array}$ & $\begin{array}{c}\text { Rank in } \\
1986-1990\end{array}$ \\
\hline Terrie E. Moffitt & Female & White & 5.0 & 24.5 & & \\
\hline William J. Wilson & Male & Non-White & 21.0 & & & \\
\hline Adelle E. Forth & Female & White & 26.0 & & & \\
\hline Alex R. Piquero & Male & Non-White & 30.5 & & & \\
\hline Megda Stoughamer-Loeber & Female & White & 36.0 & & & \\
\hline Cathy S. Widom & Female & White & 48.5 & & & \\
\hline Jacqueline Cohen & Female & White & 48.5 & 40.0 & 27.0 & 29.5 \\
\hline Christy A. Visher & Female & White & & 21.5 & 42.5 & \\
\hline Meda Chesney-Lind & Female & White & & 33.0 & & \\
\hline Janet L. Lauritsen & Female & White & & 36.5 & & \\
\hline Suzanne S. Ageton & Female & White & & 43.0 & 11.0 & 25.0 \\
\hline Joan Petersilia & Female & White & & & 35.0 & 43.0 \\
\hline Linda E. Saltzman & Female & White & & & & 29.5 \\
\hline
\end{tabular}

Three white female scholars, Moffitt (from 24.5 in 19962000 to 5 in 2001-05, Visher (from 42.5 in 1991-95 to 21.5 in 1996-2000), and Joan Petersilia (from 43 in $1986-90$ to 35 in 1991-95) made notable advances. Five (William J. Wilson, Adelle E. Forth, Alex R. Piquero, Megda Stoughamer-Loeber, and Cathy S. Wisdom) among the most-cited women and non-white scholars were ranked within the top 50 of the mostcited scholars in JRCD in 2001-05, while having not been ranked in the top 50 in the previous time periods.

From the lists of the 30 most-cited scholars in the three American criminology journals (Criminology, Journal of Quantitative Criminology, and Journal of Research in Crime and Delinquency) in 2001-2005 (Cohn 2011), 1996-2000 (Cohn and Farrington 2007a), 1991-1995 (Cohn and Farrington 1998a), and 19861990 (Cohn and Farrington 1994), women and nonwhites are identified for the current study. Table $\mathbf{5}$ shows the most-cited women and non-white scholars in the three American criminology journals in 2001-05. Among 30 most-cited scholars in 2001-2005 (Cohn, 2011), four (13.3\%) were women and non-white. As shown in Table 5, the highest rank among the most cited women and non-whites in the top 30 in 2001-05 was Terrie E. Moffitt (white female), who was ranked 4. She was also ranked $28^{\text {th }}$ in 1996-2000. Alex R. Piquero (16) was the highest ranked non-white male scholar in 2001-05. There was not a non-white male scholar in the other three time periods. There was not a non-white female scholar in any of the four time periods. Christy A. Visher (white female) was the highest ranked scholar among women and non-whites in 1996-2000, who was ranked 18, while Jacqueline Cohen was the highest ranked scholar who was ranked 9 in 1991-95 and 9 in 1986-90.
Four $(57 \%)$ of the 7 women and non-white scholars in Table 5 were ranked in the top 30 in 2001-05, three $(43 \%)$ were in the top 30 in $1996-2000$, three $(43 \%)$ were in the top 30 in 1991-1995, and three (43\%) were in the top 30 in 1986-1990. Only one of the most-cited women and non-whites in 2001-2005 was ranked in the top 30 in 1996-2000. Two of the women and non-white scholars ranked in the top 30 in 1996-2000 were also ranked in the top 30 in 1991-95, while all three of the scholars ranked in the top 30 in 1991-1995 were also ranked in the top 30 in 1986-1990.

The highest entrants in 2001-2005 having not been previously ranked in the top 30 were Alex R. Piquero (16), William J. Wilson (24), and Adelle E. Forth (24). Terrie E. Moffitt improved her ranking (from 28 in 19962000 to 4 in 2001-2005). Christy A Visher improved her ranking (from 28 in 1986-90 to 19 in 1991-95 to 18 in 1996-2000), but fell out of the top 30 by 2001-2005. Jacqueline Cohen's ranking went the opposite direction (from 9 in 1986-1995 to 18 in 1996-2000) and eventually fell out of the top 30 by 2001-05. Suzanne Ageton was able to improve her ranking (from 13 in $1986-90$ to 11 in 1991-95).

\section{American Criminal Justice Journals}

From the list of the 50 most-cited scholars in Justice Quarterly (JQ) in 2001-2005 (Cohn 2011), 1996-2000 (Cohn and Farrington 2007a), 1991-1995 (Cohn and Farrington 1998a), and 1986-1990 (Cohn and Farrington 1994), women and non-whites are identified for the current study. Table 6 shows the most-cited women and non-white scholars in JQ from 2001-05. Among 50 most-cited scholars in JQ in 2001-2005 (Cohn, 2011), six (12\%) were women and non-whites. 
Table 5: Most-Cited Women and Non-White Scholars in Three American Criminology Journals

\begin{tabular}{|c|c|c|c|c|c|c|}
\hline Name & Sex & Race & $\begin{array}{c}\text { Rank in } \\
2001-2005\end{array}$ & $\begin{array}{c}\text { Rank in } \\
1996-2000\end{array}$ & $\begin{array}{c}\text { Rank in } \\
1991-1995\end{array}$ & $\begin{array}{c}\text { Rank in } \\
1986-1990\end{array}$ \\
\hline Terrie E. Moffitt & Female & White & 4.0 & 28.0 & & \\
\hline Alex R. Piquero & Male & Non-White & 16.0 & & & \\
\hline William J. Wilson & Male & Non-White & 24.0 & & & \\
\hline Adelle E. Forth & Female & White & 24.0 & & & \\
\hline Christy A. Visher & Female & White & & 18.0 & 19.0 & 28.0 \\
\hline Jacqueline Cohen & Female & White & & 23.0 & 9.0 & 9.0 \\
\hline Suzanne S. Ageton & Female & White & & & 11.0 & 13.0 \\
\hline
\end{tabular}

As shown in Table 6, the highest rank among the women and non-whites listed in the top 50 in 2001-05 was Alex R. Piquero (non-white male) who was ranked 9. Janet L. Lauritsen (18) was the highest ranked white female scholar in JQ in 2001-05. There was not a nonwhite female scholar ranked in the top 50 in 2001-05, 1996-2000, 1991-95, or 1986-90.

Table 6 also shows the comparable rankings of these women and non-white scholars in JQ in the three previous time periods: $1996-2000,1991-95$, and 198690. From the list of the 50 most-cited scholars in JQ, eight $(16 \%)$ in 1996-2000, nine (18\%) in 1991-95, and six (12\%) in 1986-90 were women and non-whites. Meda Chesney-Lind (14.5), a white female, was the highest ranked scholar among the most-cited women and non-white scholars in JQ from 1996-2000. Joan Petersilia (11), a white female, was the highest ranked scholar among the most-cited women and non-white scholars in JQ from 1991-95. There was not a nonwhite male scholar ranked in the top 50 in JQ in 199195 or 1986-90. Jaqueline Cohen (7.5), a white female, was the highest ranked scholar among the most-cited women and non-whites in JQ in 1986-1990.

Six (32\%) of these 19 women and non-whites in JQ had been ranked in the top 50 in 2001-05, $9(47 \%)$ had been ranked in the top 50 in 1996-2000, $9(47 \%)$ had been ranked in the top 50 in 1991-95, and $6(32 \%)$ had been ranked in the top 50 in 1986-90. Three of the most-cited women and non-white scholars in JQ in 2001-05 were ranked in the top 50 in 1996-2000, while one was ranked in the top 50 in 1986-1990. Three of the most-cited women and non-white scholars in 19962000 were ranked in the top 50 in 1991-95, while two were also ranked in 1986-90. Four of the most-cited women and non-white scholars in 1991-95 were ranked in the top 50 in 1986-90.

The highest new entrant among women and nonwhites into the top most-cited scholars in JQ from
2001-05 was Alex R. Piquero (9). Other notable entrants into the top 50 in 2001-05 were Janet L. Lauritsen (18) and Kathleen F. Ferraro (39). Terrie E. Moffitt advanced her ranking (from 40 in 1996-2000 to 34 in 2001-05). Moving slightly in the other direction were William J. Wilson and Adelle E. Forth (both from 25.5 in 1996-2000 to 26.5 in 2001-05). Adelle Forth was also ranked 28 in 1986-90. Meda Chesney-Lind improved her ranking (from 16.5 in 1991-95 to 14.5 in 1996-2000). Christy A. Visher improved her ranking for three consecutive time periods (from 48.5 in 1986-1990 to 38 in 1991-95 to 27 in 1996-2000). Joan Petersilia was also ranked for three consecutive time periods (from 41 in 1986-90 to 11 in 1991-95 to 40 in 19962000). Moving in the opposite direction was Jacqueline Cohen (from 7.5 in 1986-90 to 27.5 in 1991-95). Suzanne S. Ageton improved her ranking (from 48.5 in $1986-90$ to 32.5 in 1991-95).

From the lists of the 50 most-cited scholars in the Journal of Criminal Justice (JCJ) in 2001-2005 (Cohn 2011), 1996-2000 (Cohn and Farrington 2007a), 19911995 (Cohn and Farrington 1998a), and 1986-1990 (Cohn and Farrington 1994), women and non-whites are identified for the current study. Among 50 mostcited scholars in JCJ in 2001-05 (Cohn, 2011), six $(12 \%)$ are women and non-whites. Table 7 shows the women and non-whites listed in the 50 most-cited scholars in JCJ from 2001-05. The highest rank among women and non-whites in the top 50 in 2001-05 was Terrie E. Moffitt (white female), who was ranked 6. Alex R. Piquero (15) was the highest ranked non-white male scholar in JCJ in 2001-05. There was not a single nonwhite female ranked in the top 50 in JCJ in 2001-05, 1996-2000, 1991-95, or 1986-90.

Table 7 also shows the comparable rankings of these women and non-white scholars in JCJ in the three previous time periods: $1996-2000,1991-95$, and 1986-90. From the lists of the 50 most-cited scholars in JCJ, seven (14\%) in 1996-2000, nine (18\%) in 1991- 
Table 6: Most-Cited Women and Non-White Scholars in Justice Quarterly

\begin{tabular}{|c|c|c|c|c|c|c|}
\hline Name & Sex & Race & $\begin{array}{c}\text { Rank in } \\
2001-2005\end{array}$ & $\begin{array}{c}\text { Rank in } \\
1996-2000\end{array}$ & $\begin{array}{c}\text { Rank in } \\
1991-1995\end{array}$ & $\begin{array}{c}\text { Rank in } \\
1986-1990\end{array}$ \\
\hline Alex R. Piquero & Male & Non-White & 9.0 & & & \\
\hline Janet L. Lauritsen & Female & White & 18.0 & & & \\
\hline William J. Wilson & Male & Non-White & 26.5 & 25.5 & & \\
\hline Adelle E. Forth & Female & White & 26.5 & 25.5 & & 28.0 \\
\hline Terrie E. Moffitt & Female & White & 34.0 & 40.0 & & \\
\hline Kathleen F. Ferraro & Female & Unidentified & 39.0 & & & \\
\hline Meda Chesney-Lind & Female & White & & 14.5 & 16.5 & \\
\hline Cassia Spohn & Female & White & & 25.5 & & \\
\hline Christy A. Visher & Female & White & & 27.0 & 38.0 & 48.5 \\
\hline Marjorie S. Zatz & Female & White & & 29.5 & & \\
\hline Joan Petersilia & Female & White & & 40.0 & 11.0 & 41.0 \\
\hline Martha A. Myers & Female & White & & & 27.5 & \\
\hline Jacqueline Cohen & Female & White & & & 27.5 & 7.5 \\
\hline Kathleen Daly & Female & White & & & 32.5 & \\
\hline Suzanne S. Ageton & Female & White & & & 32.5 & 48.5 \\
\hline Joan McCord & Female & White & & & 45.0 & \\
\hline Mary P. Koss & Female & White & & & 45.0 & \\
\hline Denise B. Kandel & Female & White & & & & 18.0 \\
\hline
\end{tabular}

95 , and three (6\%) in 1986-1990 were women and nonwhites. Joan Petersilia (11), a white female, was the highest ranked among women and non-whites in the list of the most-cited scholars in JCJ in 1996-2000. Petersilia (6) was also the highest ranked among women and non-white scholars in JCJ in 1991-95. There was not a non-white male scholar ranked in the top 50 in JCJ in 1996-2000 or 1986-90, while Rolando V. del Carmen (20) was the highest ranked non-white male scholar in the top 50 in JCJ in 1991-95. Jacqueline Cohen (7), a white female, was the highest ranked among women and non-white scholars on the list of the most-cited scholars in JCJ in 1986-90.

Six $(40 \%)$ of these 15 women and non-white scholars in Table 7 had been ranked in the top 50 in 2001-05, seven (47\%) were in the top 50 in 1996-2000, nine $(60 \%)$ were in the top 50 in 1991-95, and three $(20 \%)$ were in the top 50 in 1986-90. Three of the most-cited women and non-white scholars in 2001-05 were also ranked in the top 50 in 1996-2000, while two were in the top 50 in 1991-95, and one was in the top 50 in 1986-90. Of the seven most-cited women and non-white scholars in 1996-2000, four were ranked in the top 50 in 1991-95, and two were ranked in the top 50 in 1986-90. Of the nine most-cited women and nonwhite scholars in 1991-95, two were also ranked in the top 50 in 1986-90.

The highest new entrant among women and nonwhites into the top most-cited scholars in JCJ in 2001-
05 was Terrie E. Moffitt (6). Other notable first-time entrant into the top 50 in 2001-05 was Alex R. Piquero (15). The most notable advancement in rank in 19962000 to 2001-05 was Doris L. MacKenzie (from 35 to 16.5). Moving in the opposite direction, but also in the top 50 for three consecutive time periods was Nancy C. Jurik (from 34 in 1991-95 to 18.5 in 1996-2000 to 45 in 2001-05). Although absent from the top 50 in 19962000 , Susan F. Turner was in the top 50 in 1991-95 (23) and 2001-05 (45). Joan Petersilia was in the top 50 all four-time periods (22.5 in 1986-90 to 6 in 199195 ; 11 in $1996-2000$ to 22.5 in 2001-05).

From the lists of the 50 most-cited scholars in Criminal Justice and Behavior (CJB) in 2001-2005 (Cohn 2011), 1996-2000 (Cohn and Farrington 2007a), 1991-1995 (Cohn and Farrington 1998a), and 19861990 (Cohn and Farrington 1994), women and nonwhites are identified for the current study. Table 8 shows women and non-white scholars in the list of the most-cited scholars in CJB in 2001-05. Among top 50 most-cited scholars in CJB in 2001-2005 (Cohn, 2011), seven (14\%) were women and non-whites. As shown in Table 8, the highest rank among women and nonwhites in the top 50 in 2001-05 was Marnie E. Rice (white female), who was ranked 4 . There was not a non-white female or non-white male scholar ranked in the top 50 in CJB in 2001-05, 1996-2000, 1991-95, or 1986-90.

Table 8 also shows the comparable rankings of these women and non-white scholars in CJB in three 
Table 7: Most-Cited Women and Non-White Scholars in Journal of Criminal Justice

\begin{tabular}{|c|c|c|c|c|c|c|}
\hline Name & Sex & Race & $\begin{array}{c}\text { Rank in } \\
2001-2005\end{array}$ & $\begin{array}{c}\text { Rank in } \\
1996-2000\end{array}$ & $\begin{array}{c}\text { Rank in } \\
1991-1995\end{array}$ & $\begin{array}{c}\text { Rank in } \\
1986-1990\end{array}$ \\
\hline Terrie E. Moffitt & Female & White & 6.0 & & & \\
\hline Alex R. Piquero & Male & Non-White & 15.0 & & & \\
\hline Doris L. MacKenzie & Female & White & 16.5 & 35.0 & & \\
\hline Joan Petersilia & Female & White & 22.5 & 11.0 & 6.0 & 22.5 \\
\hline Nancy C. Jurik & Female & White & 45.0 & 18.5 & 34.0 & \\
\hline Susan F. Turner & Female & White & 45.0 & & 23.0 & \\
\hline Jacqueline Cohen & Female & White & & 27.5 & 18.5 & 7.0 \\
\hline Christy A. Visher & Female & White & & 31.0 & 34.0 & \\
\hline Cassia Spohn & Female & White & & 46.5 & & \\
\hline Ellen G. Cohn & Female & White & & 46.5 & & \\
\hline Rolando V. del Carmen & Male & Non-White & & & 20.0 & \\
\hline Martha A. Myers & Female & White & & & 28.0 & \\
\hline S. Folkman & Female & White & & & 34.0 & \\
\hline Belinda R. McCarthy & Female & White & & & 48.0 & \\
\hline Christine Maslach & Female & White & & & & 13.5 \\
\hline
\end{tabular}

previous time periods: $1996-2000,1991-95$, and 198690. From the lists of the 50 most-cited scholars in CJB, eleven (22\%) in 1996-2000, eight (16\%) in 1991-95, and three $(6 \%)$ in 1986-90 were women and nonwhites. Rice (Rank 4 in 1996-2000), Judith V. Becker (Rank 5 in 1991-1995), and Marguerite Q. Warren (Rank 13.5 in 1986-1990) were the most-cited scholars among women and non-whites in CJB for each time period.

Seven $(37 \%)$ of these 19 women and non-white scholars in Table 8 had been ranked in the top 50 in 2001-05, eleven (58\%) were in the top 50 in 19962000 , eight $(42 \%)$ were in the top 50 in 1991-95, and three (16\%) were in the top 50 in 1986-90. Six of the most-cited women and non-white scholars in 2001-05 were also ranked in the top 50 in 1996-2000, while one was ranked in the top 50 in 1991-95. Three of the most-cited women and non-white scholars in 19962000 were also ranked in the top 50 in 1991-95.

The highest new entrant among women and nonwhites into the top most-cited scholars in CJB in 200105 having not been previously ranked in the top 50 in any other time period was Pamela C. Robbins (34). Catherine A. Cormier (30.5 to 17), Adelle E. Forth (25.5 to 24.5), Claire E. Goggin (30.5 to 28), and Doris L. MacKenzie (45.5 to 41 ), improved their ranks in 19962000 to 2001-05. Moving in the opposite direction was Terrie E. Moffitt (from 9.5 in 1996-2000 to 37.5 in 200105). Marnie E. Rice was ranked in the top 50 in three consecutive time periods (from 19 in 1991-95 to 4 in 1996-2000 to 4 in 2001-05). Mary P. Koss improved her ranking (from 47 in 1991-95 to 35 in 1996-2000), while Judith V. Becker moved in the opposite direction during the same time period (from 5 in 1991-95 to 37.5 in 1996-2000). Joan Petersilia ranked in the top 50 in two non-consecutive time periods (from 40.5 in 198690 to 50.5 in 1996-2000).

From the lists of the 30 most-cited scholars in the three American Criminal Justice Journals (Justice Quarterly, Journal of Criminal Justice, and Criminal Justice Behavior) in 2001-2005 (Cohn 2011), 19962000 (Cohn and Farrington 2007a), 1991-1995 (Cohn and Farrington 1998a), and 1986-1990 (Cohn and Farrington 1994), women and non-whites are identified for the current study. Table 9 shows the most-cited women and non-whites ranked in the list of the mostcited scholars in the three American Criminal Justice Journals in 2001-05. Among 30 most-cited scholars in 2001-2005 (Cohn, 2011), four (13\%) were women and non-whites. As shown in Table 9, the highest rank among women and non-white non-whites in the top 30 in 2001-05 was Alex R. Piquero (non-white male), who was ranked 12. Terrie E. Moffitt (13) was the highest ranked white female in three American Criminal Justice Journals in 2001-05.

Table 9 also shows the comparable rankings of the women and non-white scholars in three American Criminal Justice Journals in the three previous time periods: 1996-2000, 1991-95, and 1986-90. From the lists of the 30 most-cited scholars in three American Criminal Justice Journals, four (13\%) in 1996-2000, four (13\%) in 1991-95, and two (7\%) in 1986-90 was women and non-whites. The highest ranked scholars among women and non-whites were Terrie E. Moffitt 
Table 8: Most-Cited Women and Non-White Scholars in Criminal Justice and Behavior

\begin{tabular}{|c|c|c|c|c|c|c|}
\hline Name & Sex & Race & $\begin{array}{c}\text { Rank in } \\
2001-2005\end{array}$ & $\begin{array}{c}\text { Rank in } \\
1996-2000\end{array}$ & $\begin{array}{c}\text { Rank in } \\
1991-1995\end{array}$ & $\begin{array}{c}\text { Rank in } \\
1986-1990\end{array}$ \\
\hline $\begin{array}{l}\text { Marnie E. Rice } \\
\text { Catherine A. Cormier } \\
\text { Adele E. Forth } \\
\text { Claire E. Goggin } \\
\text { Pamela C. Robbins } \\
\text { Terrie E. Moffitt } \\
\text { Doris L. MacKenzie } \\
\text { Mary P. Koss } \\
\text { Judith V. Becker } \\
\text { Ann W. Burgess } \\
\text { Gail S. Goodman } \\
\text { Joan Petersilia } \\
\text { Martha F. Erickson } \\
\text { Patricia M. Crittenden } \\
\text { D. Daro } \\
\text { Joan McCord } \\
\text { M. S. Mittelman } \\
\text { Marguerite Q. Warren } \\
\text { Dana E. Hunt }\end{array}$ & $\begin{array}{l}\text { Female } \\
\text { Female } \\
\text { Female } \\
\text { Female } \\
\text { Female } \\
\text { Female } \\
\text { Female } \\
\text { Female } \\
\text { Female } \\
\text { Female } \\
\text { Female } \\
\text { Female } \\
\text { Female } \\
\text { Female } \\
\text { Female } \\
\text { Female } \\
\text { Female } \\
\text { Female } \\
\text { Female }\end{array}$ & $\begin{array}{l}\text { White } \\
\text { White } \\
\text { White } \\
\text { White } \\
\text { White } \\
\text { White } \\
\text { White } \\
\text { White } \\
\text { Unidentified } \\
\text { Unidentified } \\
\text { White } \\
\text { White } \\
\text { White } \\
\text { White } \\
\text { White } \\
\text { White } \\
\text { White } \\
\text { White } \\
\text { Unidentified }\end{array}$ & $\begin{array}{c}4.0 \\
17.0 \\
24.5 \\
28.0 \\
34.0 \\
37.5 \\
41.0\end{array}$ & $\begin{array}{c}4.0 \\
30.5 \\
25.5 \\
30.5 \\
\\
9.5 \\
45.5 \\
35.0 \\
37.5 \\
42.0 \\
50.5 \\
50.5\end{array}$ & $\begin{array}{c} \\
47.0 \\
5.0 \\
\\
\\
33.0 \\
33.0 \\
47.0 \\
47.0 \\
47.0\end{array}$ & $\begin{array}{r}40.5 \\
\\
13.5 \\
33.5\end{array}$ \\
\hline
\end{tabular}

(17) in 1996-2000, Joan Petersilia (7) in 1991-1995, and Jacqueline Cohen (7.5) in 1986-90.

Four (44\%) of the nine women and non-white scholars in Table 9 were ranked in the top 30 in 200105, four (44\%) were in the top 30 in 1996-2000, four $(44 \%)$ were in the top 30 in $1991-95$, and two (22\%) were in the top 30 in 1986-90. Two of the most-cited women and non-white scholars in 2001-05 were ranked in the top 30 in 1996-2000. One of the most-cited women and non-white scholars in 1996-2000 was also ranked in the top 30 in 1991-95. Two of the most-cited women and non-white scholars in 1991-95 were also ranked in the top 30 in 1986-90.

The highest ranked entrants among women and non-whites in 2001-05 having not been previously ranked in the top 30 were Alex R. Piquero (12) and
Doris L. MacKenzie (27). Terrie E. Moffitt improved her ranking (from 17 in 1996-2000 to 13 in 2001-05). Marnie E. Rich also improved her ranking (from 24.5 in 1996-2000 to 24 in 2001-2005). Joan Peterisilia was ranked in three consecutive time periods (from 23.5 in $1986-1990$ to 7 in 1991-95 to 18 in 1996-2000). Moving in the opposite direction was Jacqueline Cohen (from 7.5 in 1986-1990 to 16 in 1991-1995).

\section{Most-Cited Women and Non-White Scholars in Six Journals}

Previous studies calculated a combined measure of the influence in all six journals in 2001-2005 (Cohn 2011), 1996-2000 (Cohn and Farrington 2007a), 19911995 (Cohn and Farrington 1998a), and 1986-1990 (Cohn and Farrington 1994) by adding scores in the three criminology journals and scores in the three

Table 9: Most-Cited Women and Non-White Scholars in Three American Criminal Justice Journals

\begin{tabular}{|c|c|c|c|c|c|c|}
\hline Name & Sex & Race & $\begin{array}{c}\text { Rank in } \\
2001-2005\end{array}$ & $\begin{array}{c}\text { Rank in } \\
1996-2000\end{array}$ & $\begin{array}{c}\text { Rank in } \\
1991-1995\end{array}$ & $\begin{array}{c}\text { Rank in } \\
1986-1990\end{array}$ \\
\hline Alex R. Piquero & Male & Non-White & 12.0 & & & \\
\hline Terrie E. Moffitt & Female & White & 13.0 & 17.0 & & \\
\hline Marnie E. Rice & Female & White & 24.0 & 24.5 & & \\
\hline Doris L. MacKenzie & Female & White & 27.0 & & & \\
\hline Joan Petersilia & Female & White & & 18.0 & 7.0 & 23.5 \\
\hline Christy A. Visher & Female & White & & 30.5 & & \\
\hline Jacqueline Cohen & Female & White & & & 16.0 & 7.5 \\
\hline Martha A. Myers & Female & White & & & 26.0 & \\
\hline Judith V. Becker & Female & Unidentified & & & 27.0 & \\
\hline
\end{tabular}


Table 10: Top 10 Most-Cited Scholars in Six Journals

\begin{tabular}{|c|c|c|c|c|c|c|}
\hline Name & Sex & Race & $\begin{array}{c}\text { Rank in } \\
2001-2005\end{array}$ & $\begin{array}{c}\text { Rank in } \\
1996-2000\end{array}$ & $\begin{array}{c}\text { Rank in } \\
1991-1995\end{array}$ & $\begin{array}{c}\text { Rank in } \\
1986-1990\end{array}$ \\
\hline $\begin{array}{c}\text { David P. Farrington } \\
\text { Robert J. Sampson } \\
\text { Travis Hirschi } \\
\text { Francis T. Cullen } \\
\text { Raymond Paternoster Michael R. } \\
\text { Gottfredson, } \\
\text { Daniel S. Nagin, } \\
\text { Terrie E. Moffitt } \\
\text { John H. Laub } \\
\text { Robert J. Bursik } \\
\text { Delbert S. Elliott } \\
\text { John L. Hagan } \\
\text { David Huizinga } \\
\text { Robert Agnew } \\
\text { Douglas A. Smith } \\
\text { Alfred Blumstein } \\
\text { Lawrence E. Cohen } \\
\text { Marvin E. Wolfgang } \\
\text { Michael J. Hindelang } \\
\text { Jacqueline Cohen } \\
\text { James Q. Wilson }\end{array}$ & $\begin{array}{l}\text { Male } \\
\text { Male } \\
\text { Male } \\
\text { Male } \\
\text { Male } \\
\text { Male } \\
\text { Male } \\
\text { Female } \\
\text { Male } \\
\text { Male } \\
\text { Male } \\
\text { Male } \\
\text { Male } \\
\text { Male } \\
\text { Male } \\
\text { Male } \\
\text { Male } \\
\text { Male } \\
\text { Male } \\
\text { Female } \\
\text { Male }\end{array}$ & $\begin{array}{l}\text { White } \\
\text { White } \\
\text { White } \\
\text { White } \\
\text { White } \\
\text { White } \\
\text { White } \\
\text { White } \\
\text { White } \\
\text { White } \\
\text { White } \\
\text { White } \\
\text { White } \\
\text { White } \\
\text { White } \\
\text { White } \\
\text { White } \\
\text { White } \\
\text { White } \\
\text { White } \\
\text { White }\end{array}$ & $\begin{array}{l}\frac{1.0}{2.0} \\
\underline{3.0} \\
\frac{4.0}{5.0} \\
\frac{6.0}{7.0} \\
\underline{8.0} \\
\underline{9.0} \\
\underline{10.0} \\
17.0 \\
19.0 \\
21.0 \\
14.0 \\
16.0 \\
32.0 \\
34.0\end{array}$ & $\begin{array}{c}\frac{3.0}{4.0} \\
\frac{1.0}{13.0} \\
19.0 \\
\underline{2.0} \\
21.0 \\
23.0 \\
11.0 \\
15.0 \\
\underline{5.0} \\
\underline{6.0} \\
\underline{7.0} \\
\underline{8.0} \\
\underline{9.0} \\
\underline{10.0} \\
22.0 \\
31.0 \\
27.0 \\
30.0 \\
25.5\end{array}$ & $\begin{array}{c}\underline{6.0} \\
\underline{3.0} \\
\frac{1.0}{14.0} \\
23.0 \\
\underline{2.0} \\
27.0 \\
36.0 \\
29.0 \\
\underline{9.0} \\
\underline{8.0} \\
\underline{7.0} \\
\frac{16.0}{4.0} \\
\underline{5.0} \\
\underline{10.0} \\
\frac{13.0}{11.0} \\
12.0\end{array}$ & $\begin{array}{c}14.0 \\
42.0 \\
\underline{4.0} \\
13.0 \\
39.0 \\
\underline{5.0}\end{array}$ \\
\hline
\end{tabular}

criminal justice journals. Table $\mathbf{1 0}$ shows the name, sex and race of the top 10 most-cited scholars on this combined measure in each time period. As seen in Table 10, all but two are white males in the top 10 most-cited scholars during this 20-year time period. Two exceptions are Terrie Moffitt and Jacqueline Cohen who are both white females. Moffitt was ranked 8 in 2001-2005, improving from 23 in 1996-2000. Jacqueline Cohen was ranked 7 in 1986-1990, but her ranking moved in the opposite direction (from 7 in 1986-1990 to 11 in 1991-1995 to 30 in 1996-2000).

From the lists of the 50 most-cited scholars in all six journals from 2001-2005 (Cohn 2011), 1996-2000 (Cohn and Farrington 2007), 1991-1995 (Cohn and Farrington 1998a), and 1986-1990 (Cohn and Farrington 1994), women and non-white scholars are identified for the current study. Table 11 shows the most-cited women and non-whites ranked in the list of the most-cited scholars in all six journals in 2001-05. Six women and non-white scholars (Terrie E. Moffitt, Alex R. Piquero, William J. Wilson, Janet L. Lauritsen, Marnie E. Rice, and Doris L. MacKenzie) were ranked in the list of the 50 most-cited scholars in all six journals in 2001-2005. Terrie Moffitt (rank 8) was the highest ranked woman and non-white scholar in 200105.
Table 11 also shows the comparable rankings of these women and non-white scholars in 1996-2000, 1991-95, and 1986-90. Seven scholars (14\%) were in the top 50 in 1996-2000, five scholars (10\%) were in the top 50 in. 1991-95, and four (8\%) were in the top 50 in 1986-90. Christy A. Visher (Rank 14) was the highest ranked scholar among women and non-whites in six journals in 1996-2000. Jacqueline Cohen (11 and 7) was the highest ranked scholar among women and non-whites in six journals in 1991-95 and 1986-90. Terrie E. Moffitt (23), William J. Wilson (39.5), and Marnie E. Rice (46) were able to remain in the top 50 from 1996-2000 to 2001-2005. Moffitt increased her ranking (from 23 in 1996-2000 to 8 in 2001-05). William $\mathrm{J}$. Wilson also increased his ranking (from 39.5 in 1996-2000 to 30 in 2001-05). Additionally, Marnie E. Rice slightly increased her ranking (from 46 in 19962000 to 45 in 2001-05). Christy A. Visher, Jacqueline Cohen, and Joan Petersilia were all able to rank in the top 50 in three consecutive time periods (from 19861990 to 1991-1995 to 1996-2000). Christy A. Visher improved her ranking (from 45.5 in 1986-90 to 21 in 1991-95 to 14 in 1996-2000). Jacqueline Cohen saw her ranking go in the other direction (from 7 in 1986-90 to 11 in 1991-95 to 30 in 1996-2000). Joan Petersilia's ranking during three consecutive time periods saw improvement and a decrease (from 32 in 1986-90 to 17 in 1991-95 to 39.5 in 1996-2000). Suzanne S. Ageton 
Table 11: Most-Cited Women and Non-White Scholars in Six Journals

\begin{tabular}{|c|c|c|c|c|c|c|}
\hline Name & Sex & Race & $\begin{array}{c}\text { Rank in } \\
2001-2005\end{array}$ & $\begin{array}{c}\text { Rank in } \\
1996-2000\end{array}$ & $\begin{array}{c}\text { Rank in } \\
1991-1995\end{array}$ & $\begin{array}{c}\text { Rank in } \\
1986-1990\end{array}$ \\
\hline Terrie E. Moffitt & Female & White & 8.0 & 23.0 & & \\
\hline Alex R. Piquero & Male & Non-White & 12.0 & & & \\
\hline William J. Wilson & Male & Non-White & 30.0 & 39.5 & & \\
\hline Janet L. Lauritsen & Female & White & 36.0 & & & \\
\hline Marnie E. Rice & Female & White & 45.0 & 46.0 & & \\
\hline Doris L. Mackenzie & Female & White & 48.0 & & & \\
\hline Christy A. Visher & Female & White & & 14.0 & 21.0 & 45.5 \\
\hline Jacqueline Cohen & Female & White & & 30.0 & 11.0 & 7.0 \\
\hline Meda Chesney-Lind & Female & White & & 37.0 & & \\
\hline Joan Petersilia & Female & White & & 39.5 & 17.0 & 32.0 \\
\hline Suzanne S. Ageton & Female & White & & & 19.0 & 24.5 \\
\hline Marthat A. Myers & Female & White & & & 45.0 & \\
\hline Judith V. Becker & Female & Unidentified & & & 46.0 & \\
\hline
\end{tabular}

increased her ranking (from 24.5 in 1986-1990 to 19 in 1991-95).

\section{CONCLUSIONS}

Scholars often criticize that women and non-white scholars are inadequately represented as authors of articles published in leading criminology and criminal justice journals and textbooks, as editorial representatives (editors, associate editors, and editorial board members) of the journals, and membership in national and professional associations in criminology and criminal justice (the American Society of Criminology and the Academy of Criminal Justice Sciences) (Miller et al. 2000; Rice, Terry, Miller, and Ackerman 2007; Tatum 2002). The current study examines this claim by examining if the dissemination of published research findings in criminology and criminal justice is affected by gender and race/ethnicity. Specifically, from the lists of the most-cited scholars in six mainstream criminology and criminal justice journals in 2001-2005 (Cohn 2011), 1996-2000 (Cohn and Farrington 2007a), 1991-1995 (Cohn and Farrington 1998a), and 1986-1990 (Cohn and Farrington 1994), this study identified women and nonwhite scholars rankings.

This study of citation trends in six major journals over 20 years shows that the inclusion process is not yet achieved and works by women and non-white criminologists continue to lack visibility in the more prestigious criminal justice and criminology journals. Two hundred seventy scholars $(77.1 \%)$ ranked in the top 50 at least once in any of the six journals in 19862005 were white males, while $44(12.6 \%)$ are white females. Comparatively, there are six non-white males $(1.7 \%)$ and only one non-white female (.3\%), which accounted for $2.0 \%$ of the total representation of mostcited scholars to appear at least once in the top 50 in any of the six journals over 20 years. Overall, Terrie E. Moffitt (white female) and Alex R. Piquero (non-white male) were the most-cited women and non-white scholars in these six journals from 2001-2005, compared with Jacqueline Cohen (white female) in 1986-1995.

It is plausible that the over-representation of whitemales and the seeming under-representation of women and non-whites in citations reflects the notion that white male scholars have been around longer in the discipline and thus have had a greater length of time to make large contributions and thus, only time is the matter for high citations of works by women and nonwhites. Interestingly, a gender shift is underway in CCJ. As Rice, Terry, Miller and Ackerman (2007) explain, the majority of currently active CCJ doctoral students are female and 57 percent of all newly enrolled graduate students are female, while only 35 percent of all fulltime CCJ faculties are female. They suggest that (if admission patterns hold) women will soon comprise the majority in the discipline of CCJ. The current study is limited to examining articles published from 1986-2005 in six major American CCJ journals. Using more recently published articles, future studies should examine if the time is ripe for a targeted explication of citation trends of women and non-whites scholars.

A number of other explanations might be offered to account for gender as well as racial differentials in publication rates and citation rates. First, lower 
publication rates by women and non-whites and lower citation rates of their works by colleagues might be attributed to research topics (Rice et al. 2007). Most apparent is the greater likelihood that women and nonwhite criminology and criminal justice scholars devote a large proportion of their research to women and racerelated topics (Edwards, white, Bennett, and Pezzella 1998; Ross and Edwards, 1998; Tatum, 2002). Tatum (2002) suggests this type of scholarship may be viewed as being too narrow (e.g. only examining African Americans or only examining women) or too subjective (e.g. lacking a value free analysis) by mainstream journals (Wilson and Moyer 1995; Tatum 2002). These views are more likely to be expressed when there are few or no women and racial non-whites on editorial boards (Tatum, 2002). Since it is unlikely that the mainstream journals in criminology and criminal justice are primary outlets for research addressing women and race/ethnicity issues (Tatum, 2000), this may account for why research by women and non-white scholars is less likely to be cited in the mainstream criminology and criminal justice journals. In fact, the finding of the current study that two relatively young scholars, Terrie E. Moffitt (white female) and Alex R. Piquero (nonwhite male) were the most-cited women and non-white scholars from 2001-2005 might be due to their research topics which are very popular in the field; Moffitt's works on life-course/developmental criminology and Piqeuro's works on juvenile offenders.

Even if women and non-white scholars succeed in publishing their works on women and non-white topics using female and racial minority samples in leading journals, criminology and criminal justice will remain white male-dominated until the findings of this research are disseminated to larger audiences. Ferber (1986), Miller, Wright and Smith (2000), and Taylor Greene and Gabbidon (2003) suggest that citations in academic publications are sensitive to gender and race; authors are more likely to cite works written by members of their own sex and race. In the discipline of criminology and criminal justice where white men are overrepresented, women and non-white scholars are disadvantaged in gaining recognition for their work (Taylor Greene and Gabbidon 2003; Miller et al. 2000).

The content of articles published in journals, and hence their citations, is also likely to be influenced by the identity of editors and editorial board members. It was noteworthy that journal editors tended to be highly cited in the present analyses. It has been argued that scholars sometimes try to increase their perceived chance to have an article accepted for publication by citing journal editors or editorial board members (Cohn 2011; Rushton 1984). In fact, all of the editors ranked in the lists of the most-cited scholars in six journals over 20 years are white males (Cohn 2011). Future research is required to examine the relationships of gender and racial compositions of editors and editorial board members with those of most-cited scholars in each journal.

Authors of this study are aware of the limitations of our citation analysis. One of the major limitations is the exclusion of article appearing in international journals (e.g. International Journal of Comparative and Applied Criminal Justice and International Journal of Offender Therapy and Comparative Criminology), more specialized journals (e.g. women and Criminal Justice Journals and Violence and Victims), race and ethnicity journals (e.g. Journal of Ethnicity in Criminal Justice) in which women and non-white scholars usually attempt to publish (Edwards, et al. 1998; Tatum 2002; Wilson and Moyer 1995). As a result, it may underestimate the influence of those women and non-white scholars who publish mainly in other journals (Cohn 2007b, 2011). Arguably, the most-cited scholars are, at least to some extent, specific to particular journals, and that the results would differ if other journals were analyzed. Additionally, this research does not include an analysis of the citations from classic books written by women and non-whites such as The Truly Disadvantaged (Wilson 1987), When Work Disappears (Wilson 1996), and Code of the Street (Anderson 1999) nor does it take into account the progress made by women and non-white scholars as evidenced by awards and other recognitions received such as Ruth Peterson's receipt of the prestigious Edwin Sutherland Award from the American Society of Criminology in 2011.

One possible way to investigate these concerns for future research is to study the most-cited scholars in specific subareas of CCJ and to expand the number of CCJ journals to include some that were slightly less mainstream (Cohn and Farrington 2008). In fact, Cohn and Farrington (1998b, 2007b) counted all authors cited in all articles in four major international journals of the English-speaking world (ANZ, Australian and New Zealand Journal of Criminology; BJC, British Journal of Criminology; CJC, Canadian Journal of Criminology and Criminal Justice; CRIM, Criminology). Cohn and Farrington (2007b) found 11 female scholars from the list of the most cited scholars in ANZ in 1996 to 2000 (those with ranks up to 50), more than in any of the other three journals (Cohn and Farrington 2007b). Cohn and Farrington (2008), expanded their number of 
CCJ journals coverage to twenty (five American criminology journals, five American criminal justice journals, five international criminology journals, and five international criminal justice journals). This revealed international scholars such as John Braithwaite and Richard V. Ericson and scholars in less mainstream areas such as Murray A. Straus remain prevalent in their impact on CCJ. Furthermore, it is relevant to posit that future research focuses on the possibility that nonwhites and women cite other non-whites and women more frequently than whites and males.

The use of additional journals has both advantages and disadvantages. The advantages of increased coverage were to some extent counteracted by the disadvantages of including progressively less mainstream CCJ journals. Expanding the analysis to even more journals would increase the visibility of women and non-white scholars who publish in more specialized fields. The present results depend to a considerable extent on the choice of journals to be analyzed (Cohn and Farrington 2008). Lastly, future research on women and non-white scholars should seek to further categorize race/ethnicity. Simply dichotomizing race/ethnicity as white or non-white fails to capture richer data of the differentiations within specific groups of non-white scholars.

Paper presented at the Annual Meeting Sponsored by Affirmative Action Committee of the Academy of Criminal Justice Science on March 15, 2012 in New York

\section{ACKNOWLEDEGMENT}

We thank Alida V. Merlo and Alex R. Piquero for their comments and suggestions. These comments and suggestions greatly helped in revising the paper.

\section{REFERENCES}

Anderson, Elijah. 1999. "Code of the Street: Decency, Violence, and the Moral Life of the Inner City." New York: W.W. Norton and Company.

Chesney-Lind, Meda. 1989. 'Girls' Crime and Woman's Place: Toward a Feminist Model of Female Delinquency." Crime and Delinquency 35:5-29. http://dx.doi.org/10.1177/0011128789035001002

Christenson, James A., and Lee Sigelman. 1985. "Accrediting Knowledge: Journal Stature and Citation Impact in Social Science." Social Science Quarterly 66:964-75.

Cohn, Ellen G. 2011. "Changes in Scholarly Influence in Major American Criminology and Criminal Justice Journals Between 1986 and 2005." Journal of Criminal Justice Education 22(4):493-525.

http://dx.doi.org/10.1080/10511253.2011.556134
Cohn, Ellen G. and David P. Farrington 1994. "Who are the Mostcited Scholars in Major American Criminology and Criminal Justice Journals?" Journal of Criminal Justice 22: 517-34. http://dx.doi.org/10.1016/0047-2352(94)90093-0

Cohn, Ellen G. and David P. Farrington 1998a. "Changes in the Most-cited Scholars in Major American Criminology and Criminal Justice Journals between 1986-90 and 1991-95." Journal of Criminal Justice 26:99-116. http://dx.doi.org/10.1016/S0047-2352(97)00073-1

Cohn, Ellen G. and David P. Farrington 1998b. "Changes in the Most-Cited Scholars in Major International Journals between 1986-90 and 1991-95." British Journal of Criminology 38:156-70.

http://dx.doi.org/10.1093/oxfordjournals.bjc.a014218

Cohn, Ellen G., and David P. Farrington 1999. "Changes in the Mostcited Scholars in Twenty Criminology and Criminal Justice Journals between 1990 and 1995." Journal of Criminal Justice 27(4):345-359.

http://dx.doi.org/10.1016/S0047-2352(99)00006-9

Cohn, Ellen G. and David P. Farrington 2007a. "Changes in Scholarly Influence in Major American Criminology and Criminal Justice Journals between 1986 and 2000." Journal of Criminal Justice Education 18:6-34. http://dx.doi.org/10.1080/10511250601144225

Cohn, Ellen G. and David P. Farrington 2007b. "Changes in Scholarly Influence in Major International Criminology Journals." The Australian and New Zealand Journal of Criminology 40(3):335-359. http://dx.doi.org/10.1375/acri.40.3.335

Cohn, Ellen G. and David P. Farrington 2008. "Scholarly Influence in Criminology and Criminal Justice Journals in 1990-2000." Journal of Criminal Justice 36:11-21. http://dx.doi.org/10.1016/j.jcrimjus.2007.12.002

Cole, Jonathan R. and Stephen Cole 1971. "Measuring the Quality of Sociological Research: Problems in the Use of the Science Citation Index." The American Sociologist 6:23-9.

Daly, Kathleen and Meda Chesney-Lind 1988. "Feminism and Criminology." Justice Quarterly 5:497-535. http://dx.doi.org/10.1080/07418828800089871

Del Carmen, Alex and Robert Bing 2000. "Academic Productivity of African Americans in Criminology and Criminal Justice." Journal of Criminal Justice Education 11:237-49. http://dx.doi.org/10.1080/10511250000084891

Edwards, Willie, Ingrid Bennett, Norm White, and Frank Pezzella 1998. "Who has come out of the Pipeline? African-Americans in Criminology and Criminal Justice." Journal of Criminal Justice Education 9:249-66. http://dx.doi.org/10.1080/10511259800084311

Eigenberg, Helen and Agnes Baro 1992. "Women and the Publication Process: A Content Analysis of Criminal Justice Journals." Journal of Criminal Justice Education 3:293-314. http://dx.doi.org/10.1080/10511259200082681

Ferber, Marianne A. 1986. "Citations: Are they an Objective Measure of Scholarly Merit?" Journal of Women in Culture and Society 11:381-389. http://dx.doi.org/10.1086/494230

Free, Marvin D. (1999). "Racial Issues in Contemporary Criminology Textbooks: The Case of African Americans." Contemporary Justice Review 1:429-466.

Gabbidon, Shaun L. and Rebekah Collins 2012. "Using Google Scholar to Determine the Most Cited Criminology and Criminal Justice-related Books." American Journal of Criminal Justice 37:33-45. http://dx.doi.org/10.1007/s12103-011-9130-6

Gabbidon, Shaun L. and Favian Martin 2010. "An Era-based Exploration of the Most Significant Books in Criminology/criminal justice: A Research Note." Journal of Criminal Justice Education 21(3):348-369. http://dx.doi.org/10.1080/10511253.2010.487833 
Gabbidon, Shaun L. and Helen Taylor Greene 2001. "The Presence of African American Scholarship in Early American Criminology Text (1981-1960)." Journal of Criminal Justice Education 12:301-310.

http://dx.doi.org/10.1080/10511250100086131

Gabbidon, Shaun L., Helen Taylor Green, and Kideste Wilder 2004. "Still Excluded? An Update on the Status of African American Scholars in the Discipline of Criminology and Criminal Justice." Journal of Research in Crime and Delinquency 41(4):384-406. http://dx.doi.org/10.1177/0022427803260268

Gordon, Randall A. and Pamela J. Vicari 1992. "Eminence in Social Psychology: A Comparison of Textbook Citation, Social Sciences Citation Index, and Research Productivity Rankings." Personality and Social Psychology Bulletin 18:2638. http://dx.doi.org/10.1177/0146167292181005

Hannon, Lance and Lynn R. Dufour 1998. "Still just the Study of Men and Crime: A Content Analysis." Sex Roles 38:63-71. http://dx.doi.org/10.1023/A:1018712511855

Heidensohn, Frances 1987. "Women and Crime: Questions for Criminology." In P. Carlen and A. Worrall (Eds.), Gender, crime and justice. London: Milton Keynes.

Hughes, Lorine A. 2005. "The Representation of Females in Criminological Research: A Content Analysis of American and British Journal Articles." Women and Criminal Justice, 16(1/2):1-28. http://dx.doi.org/10.1300/J012v16n01 01

Miller, J. Mitchell, Richard A. Wright, and Michelle M. Smith 2000. "Mostly Male and American": The Reporting of Women and Crime Scholarship in Introductory Criminology Textbooks." The Justice Professional 13:233-245. http://dx.doi.org/10.1080/1478601X.2000.9959590

Morris, Allison and Loraine Gelsthorpe 1991. "Feminist Perspectives in Criminology: Transforming and Transgressing." Women and Criminal Justice 2:3-26. http://dx.doi.org/10.1300/J012v02n02 02

Myers, C. Roger 1970. "Journal Citations and Scientific Eminence in Contemporary Psychology.” American Psychologist 25:104148.

http://dx.doi.org/10.1037/h0030149

Naffine, Ngaire 1996. "Feminism and Criminology." Philadelphia: Temple University Press.

Renzetti, Claire 1993. "On the Margins of the Male stream (or, They still don't get it, do they?): Feminist Analyses in Criminal Justice Education." Journal of Criminal Justice Education 4:219-234. http://dx.doi.org/10.1080/10511259300086111

Rice, Stephen. K., Karen J. Terry, Holly V. Miller, and Alissa R. Ackerman 2007. "Research Trajectories of Female Scholars in Criminology and Criminal Justice." Journal of Criminal Justice Education 18(3):360-384.

Ross, Lee and Willie Edwards 1998. "Publishing among African American Criminologists: A Devaluing Experience?" Journal of Criminal Justice 26:29-40.

http://dx.doi.org/10.1016/S0047-2352(97)00052-4

Rushton, J. Philippe 1984. "Evaluating Research Eminence in Psychology: The Construct Validity of Citation Counts." Bulletin of the British Psychological Society 37:33-6.
Rushton, J. Philippe and Norman S. Endler 1979. "More to-do about Citation Counts in British Psychology." Bulletin of the British Psychological Society 32:107-9.

Smart, Carol 1976. "Women, crime, and criminology." London: Routledge and Kegan Paul.

Tatum, Becky L 2002. "Publication Outlets for Criminology and Criminal Justice Scholars: A Look at Race and Ethnicity Journals." Journal of Criminal Justice Education 13(1):201222.

Taylor Greene, Helen and Shaun L. Gabbidon 2003. "African American Scholarship in Criminological Research Published in the 1990s: A Content Analysis." Journal of Criminal Justice Education 14(1):1-15.

Taylor Greene, Helen, Shaun L. Gabbidon, and Myischa Ebersole 2001. "A Multi-faceted Analysis of the Presence of African American in Juvenile Delinquency Texts Published between 1997 and 2000." Journal of Crime and Justice 24:87-101.

Wilson, William J. 1997. "When Work Disappears: The World of the New Urban Poor." New York, NY: Vintage Books.

Wilson, William J 1987. "The Truly Disadvantaged: The Inner City, the Underclass, and Public Policy." Illinois: University of Chicago Press.

Wilson, Nanci and Imogene Moyer 1995. "Affirmative Action, Multiculturalism, and Criminology." In B. Price and N. Sokoloff (eds.) The Criminal Justice system and Women, pp. 421-32. New York: McGraw Hill Publishers.

Wright, Richard A., Kevin M. Bryant, and Mitchell Miller 2001. "Top Criminals/top Criminologists: The Most-cited Authors and Works in White-collar Crime." Journal of Contemporary Criminal Justice 17:383-99. http://dx.doi.org/10.1177/1043986201017004007

Wright, Richard A. and David O. Friedrichs 1998. "The Most-cited Scholars and Works in Critical Criminology." Journal of Criminal Justice Education 9:211-31. http://dx.doi.org/10.1080/10511259800084291

Wright, Richard A. and Mitchell Miller 1998. "The Most-cited Scholars and Works in Police Studies." Policing: An International Journal of Police Strategies and Management 21:240-54. http://dx.doi.org/10.1108/13639519810220154

Wright, Richard A. and Mitchell Miller 1999. "The Most-cited Scholars and Works in Corrections." The Prison Journal 79:5-22. http://dx.doi.org/10.1177/0032885599079001002

Wright, Richard A. and Cindy Sheridan 1997. "The Most-cited Scholars and Works in Women and Crime Publications." Women and Criminal Justice 9:41-60. http://dx.doi.org/10.1300/J012v09n02 03

Young, Vernetta D. and Helen Taylor Greene 1995. "Pedagogical Reconstruction: Incorporating African-American Perspectives into the Curriculum." Journal of Criminal Justice Education 6(1):85-104. http://dx.doi.org/10.1080/10511259500083341

Young, Vernetta D. and Anne T. Sulton 1991. "Excluded the Current Status of African American Scholars in the Field of Criminology and Criminal Justice." Journal of Research in Crime and Delinquency 28:101-16. http://dx.doi.org/10.1177/0022427891028001006

Received on 08-07-2013 Accepted on 19-08-2013 Published on 27-08-2013

DOI: http://dx.doi.org/10.6000/1929-4409.2013.02.30

(C) 2013 Kim and Hawkins; Licensee Lifescience Global.

This is an open access article licensed under the terms of the Creative Commons Attribution Non-Commercial License (http://creativecommons.org/licenses/by-nc/3.0/) which permits unrestricted, non-commercial use, distribution and reproduction in any medium, provided the work is properly cited. 